\title{
ECCLESIA GHANA: REALISING AFRO- CATHOLICISM IN GHANA
}

\section{Daniel John Pratt Morris-Chapman}

University of Pretoria

danielmorrischapman@yahoo.co.uk

\section{ABSTRACT}

What is the essence of the Gospel? Which aspects of the church's ministry are contingent? The story of the Anglican Church in Ghana offers an opportunity to reflect upon these questions. While the history of this colonial church is fraught with ethnocentrism, it also demonstrates a number of ways in which a rich theological tradition can be realised on Ghanaian soil. This essay explores these possibilities with the hope of identifying an authentic Afro-Catholicism.

Key words: Ghana; Anglican Church; Anglo-Catholicism; Afro-Catholicism; ethnocentrism; church ministry

\section{Introduction}

In his work, The Anglican story in Ghana (2006), Pobee states that:

Ghana represents one of the few vestiges of raw Anglo-Catholicism in the world. It is yet to take this tradition and rework it according to African integrity, genius, and use, so that it can really be at the wavelength of African Anglicanism and take root in the African, Ghanaian soil. (Pobee 2006, 29)

\section{UNISA $\cong$}

Studia Historiae Ecclesiasticae Volume 41 | Number 1 | 2015 pp. 86-104
DOI: http://dx.doi.org/10.17159/2412-4265/2015/v41n1a7 Print ISSN 1017-0499 | Online 2374-3689 (C) 2015. Studia Historiae Ecclesiasticae 
The Anglican Mission to Ghana was firmly rooted within the High Church tradition. However it would appear that the seeds of Anglo-Catholicism have failed to take root within the local context. While Pobee's (2006) brilliant work proves that the days of Englishmen narrating the story of Christianity in Africa are at an end, an Anglo-Saxon perspective on the fortunes of the Anglican Church in Ghana has its advantages. In this essay we will examine whether Pobee's vision of a 'GhanaianCatholicism' has been hindered by certain aspects of the Anglo-Catholic Mission to Ghana in the early twentieth century. It is hoped that by offering a critique of the features peculiar to the Reformation in England, the Ghanaian church can be emancipated from unnecessary Anglo-Saxon impediments in order to pursue a truly authentic Afro-Catholicism. Before proceeding, it must be stated that this paper makes no apologies for drawing liberally upon Pobee's (2006) work, which remains the only book dedicated to this particular Ghanaian church.

\section{Characteristics of Anglo-Catholicism}

\section{Veneration of tradition}

A key feature of Anglo-Catholicism ${ }^{1}$ is its veneration for the traditions and practices of the early church. Unlike other Reformed churches in Europe, the Church of England began with the divorce of Henry VIII (1491-1547). ${ }^{2}$ To all intents and purposes Henry made himself the Pope of the Catholic Church in England (Losch 2002, 106-108). ${ }^{3}$ By making himself the 'Head of the Church' Henry cast the English church in an Erastian ${ }^{4}$ mould which has ensured its close connection with the state (Pobee 2006, 18-21). ${ }^{5}$ In spite of this, Avis (2002) maintains that although the Church of England is established it has managed to retain its own inner integrity. Whether or not this rings true in the Gold Coast during the era of British colonialism remains to be seen (Avis 2002).

While the origins of the Anglican Church are unconventional they have had a constructive impact upon the evolution of this church. To be more specific, it has given Anglicanism a distinctive emphasis on tradition that is not so readily visible in other protestant denominations. ${ }^{6}$ The following extract from Thomas Ken (16371711) (quoted in Bowles 1831) illustrates the nature of this importance:

As for my religion, I die in the Holy, Catholic and Apostolic Faith professed by the whole Church before the disunion of East and West; and, more particularly, in the Communion of the Church of England, as it stands distinguished from both Papal and Protestant innovation, and adheres to the Doctrine of the Cross. (Bowles 1831, 34)

As this quotation from Ken indicates, an appeal to the traditions of the early church has enabled Anglicanism to steer a middle course between Protestantism and Roman Catholic theology. ${ }^{7}$ The distinctiveness of the Anglican theological position is also 
illustrated in Jebb's (1775-1833) Peculiar character of the Church of England (1815):

The Church of England occupies a very peculiar station in the Christian world; constituting, as it were, a species in her... The Church of Rome fetters the judgment, by implicit submission to authority. Foreign branches of the Reformation give unbounded licence to the fancy, by the unrestricted exercise of private interpretation. But our national Church inculcates a liberal, discriminative, yet undeviating reverence for pious antiquity...This principle is, in truth, our special characteristic: a principle which has ever enabled our Church to combine discursiveness with consistency, freedom of inquiry with orthodoxy of belief, and vigorous good sense with primitive and elevated piety. (Jebb 1839,3)

Here Jebb (1839) maintains that Anglicanism is unique because it gives the undivided Church of Antiquity greater authority than other Reformed churches or the present Church of Rome.

Over the course of time Anglican divines have used Antiquity 8 to justify the position of the Church of England. For example, John Jewel (1522-1571), John Bramhall (1594-1663), William Beveridge (1637-1708), and John Henry Newman (1801-1890) argued that many Roman Catholic doctrines were novel inventions; absent from the teaching of the early church (Jewel 1839, 121; Bramhall 1845, 252; Beveridge 1837, 128; Newman 1837, 47-48). ${ }^{9}$ Other Anglican divines, such as Richard Hooker (1554-1600), have used tradition to challenge the Puritan emphasis upon Sola Scriptura (Hooker 1821, 234-235). The following extract from Daniel Waterland (1683-1740) indicates the nature of this approach:

Antiquity ought to attend as a handmaid to Scripture, to wait upon her as her mistress, and to observe her to keep off intruders from making too bold with her, and to discourage strangers from misrepresenting her. Antiquity, in this ministerial view, is of very great use. (Waterland $1856,604)$

Here the doctrines of the primitive church are viewed as a hermeneutical tool necessary for interpreting the true meaning of Scripture. Thus while the Thirty Nine Articles state that "Holy Scripture containeth all things necessary to salvation"10 Anglican theologians have continued to argue that tradition is necessary for bringing out the true meaning of Scripture. ${ }^{11}$

\section{Underestimation of Scripture}

It is unfortunate that in some cases the veneration for tradition characteristic of Anglo-Catholic writers has led to an underestimation of Scripture. An example of this tendency is found in the following extract from Newman's writings:

Nothing should be preached to be religiously held by the people, but what is agreeable to Scripture doctrine, and gathered thence by the "Catholic Fathers and ancient Bishops." This then is a second restriction, and, acting under these two, we may safely say that the Church, i.e. the Church Catholic, has absolute authority in matters of necessary or saving faith, and 
supersedes so far private judgment upon the text of Scripture - that, as ruling herself by Scripture and Antiquity, she may securely and implicitly be trusted in all matters of necessary doctrine; nay further, we may even grant. (Newman 1836, 379)

Here Newman argues that the interpretation of the Scriptures found in the writings of the early church fathers supersedes the individual's interpretation of the Scriptures. Even Newman's associates, Anglo-Catholics such as Hugh James Rose (1795-1838) and Samuel Francis Wood (1810-1843), confessed that at times too much stress was being laid upon Antiquity, at the expense of Scripture. ${ }^{12}$

\section{Authority: Established or episcopal?}

The veneration of tradition was also used politically. ${ }^{13}$ The Anglican Church is the established church of Great Britain. The close connection between the Church of England and the state has shaped the development of Anglo-Catholicism profoundly. Even the Oxford Movement (1833-1841), which began in reaction to government interference, was negatively influenced by this aspect of Anglicanism. One example of this is the way in which episcopal authority was emphasised by traditionalists during this nineteenth century controversy.

As long as the Anglicans had a monopoly upon the British political system the power vacuum left by Henry's separation of the English church from the authority of the pope could be filled by its privileged position within the state. However, the repeal of the Corporation Act (1828), ${ }^{14}$ Catholic Emancipation (1829) and the Reform Act (1832) undermined this influence considerably. Non-Anglicans - 'Dissenters' and 'Catholics' - could now be elected to parliament and could therefore vote upon matters connected with the governance of the church. ${ }^{15}$ The discord felt by some traditional Anglican churchmen is captured in the following extract from John Keble's (1792-1866) Assize Sermon (1833):

The Apostolical Church [Anglicanism] in this realm is henceforth only to stand in the eye of the State, as one sect among many, depending for any pre-eminence she may still appear to retain, merely upon the accident of her having a strong party in the country. (Keble 1848, 127)

Essentially these acts of reform meant that decisions concerning the Anglican Church could now be made by dissenters and Catholics. ${ }^{16}$ These fears were realised in the state's restructure of Anglican Diocese in Ireland (1833). This move undermined the authority of the bishops and destabilised the delicate balance between church and state. It provoked a strong reaction from traditionalists because it seemed as though the state would no longer support the work of the church (Gilley and Stanley 2006, 305ff).

The consequences of these political developments for Anglo-Catholic theology are significant. In making the English monarch head of the church, papal rule was substituted with the authority of the state. As relations between the church and the 
state deteriorated many Anglicans yearned for something to fill the void. ${ }^{17}$ In order to make up for this, Anglo-Catholic writers, 'Tractarians' ${ }^{18}$ like Keble, Newman and Edward Bouverie Pusey (1800-1882), produced Tracts for the times (1833-1841) which laid great stress upon the authority of the bishops (and other members of the clergy) by emphasising their apostolic link with the early church, for example:

Consider the force of that article of our Belief, "The One Catholic and Apostolic Church"... there is on earth an existing Society, Apostolic as founded by the Apostles...because except a man be of that he can be of none...This indeed is the unanimous opinion of our divines, that, as the Sacraments, so Communion CHRIST when He ascended, did not leave us orphans, but appointed representatives of Himself to the end of time?...There is a necessity of believing the Catholic Church, with the Church, is "generally necessary to salvation," in the case of those who can obtain it. If then we express our belief in the existence of One Church on earth from CHRIST'S coming to the end of all things, if there is a promise it shall continue, and if it is our duty to do our part in our generation towards its continuance, how can we with a safe conscience countenance the interference of the Nation in its concerns?... Now, may we sit still and keep silence, when efforts are making to break up, or at least materially to weaken that Ecclesiastical Body which we know is intended to last while the world endures, and the safety of which is committed to our keeping in our day? How shall we answer for it, if we transmit that Ordinance of GOD less entire than it came to us? Now what am I calling on you to do? You cannot help what has been done in Ireland; but you may protest against it. (Newman 1834)

In this Tract the Anglican Church is viewed as an heir to the ancient church. This carries with it the stamp of apostolic authority - the inference being that the state has no business interfering with Irish Diocese because the Church of England is a spiritual establishment founded by God. ${ }^{19}$ Thus the organisation of the church, its doctrines and its sacraments are not authorised by the state but by the divine succession of its bishops to the apostles:

There are some who rest their divine mission on their own unsupported assertion; others, who rest it upon their popularity; others, on their success; and others, who rest it upon their temporal distinctions. This last case has, perhaps, been too much our own; I fear we have neglected the real ground on which our authority is built,- - our APOSTOLICAL DESCENT. We have been born, not of blood, nor of the will of the flesh, nor of the will of man, but of GOD. The LORD JESUS CHRIST gave His SPIRIT to His Apostles; they in turn laid their hands on those who should succeed them; and these again on others; and so the sacred gift has been handed down to our present Bishops, who have appointed us as their assistants, and in some sense representatives. (Newman 1833)

This Tract may be interpreted as an attempt to use episcopal authority to compensate for the withdrawal of the state's sponsorship for the church. It illustrates the important place that the doctrine of 'Apostolic succession' ${ }^{20}$ holds for Anglo-Catholics. It implies that the Anglican Church has faithfully preserved both the teaching and sacramental life of the primitive church. Thus, the church's doctrines have authority because they are guaranteed by the bishops' succession, and its sacraments have efficacy 
because they are administered by priests, who are in turn ordained by the bishops. Thus while the power of the state may have been abused, the complexity of this historic church-state relationship has had an enormous impact upon the development of Anglo-Catholicism and the way in which it understands the authority of its clergy.

Therefore, in an attempt to forge an identity within an established church, Anglo-Catholics lay great stress upon the traditions of the primitive church, the episcopate and the sacramental authority of its priests. Unfortunately these emphases can lead inadvertently to authoritarianism, clericalism, a deprecation of Scripture and individual private judgment. Having indicated some of the special features of Anglo-Catholicism, it is now necessary to explore how these characteristics have impacted upon the Anglican Mission to Ghana.

\section{Anglicanism in Ghana}

\section{The Society for the Propagation of the Gospel}

The Church of England's Mission to Ghana was largely undertaken by the Anglican missionary organisation The Society for the Propagation of the Gospel (SPG). The SPG was distinctive from the church's other missionary organisations, such as the Church Mission Society (CMS), because it was established to maintain clergy within the High Church tradition (O'Connor 2000, 10). Thus, in large part, the mission to Ghana was undertaken by priests seeking to uphold Anglo-Catholic beliefs and practices.

The first missionary, Thomas Thompson (1708-1773), began his work during the height of the slave trade in the mid-eighteenth century (1751-1756). According to Smith:

At Cape Coast Castle between [1751] and 1824, English clergymen had been sent out by the Society for the Propagation of the Gospel...The first of these, Thomas Thompson, remained in the country for five years...In spite of his calling, Thompson saw nothing evil in the slave trade and in 1772 even published a pamphlet in its defence. (Smith 1966, 22-23)

Thompson's views on the slave trade are inexcusable. The chapel in Cape Coast Castle was situated directly above the dungeons in which slaves were dying (Gaines $2006,280)$. At this early stage it is clear that the church's relationship with a state that profited from the trafficking of human beings totally undermined its proclamation of the Gospel to Ghanaian people. ${ }^{21}$

On his return to England (1756) Thompson arranged for the training of a Ghanaian priest, the Fante Phillip Quaque (Kwaku), who after ordination in Exeter returned to Cape Coast Castle (1765) to serve as a missionary (Kpobi 2008, 79). Pobee (2006) considers that Quaque's story raises further questions about Anglicanism's heritage of establishment: 
Quaque's travels on the coast always went where there was a British trading post...such a linking can be ambivalent. For example, Governor William Fielde thought he was entitled to order him to take up arms in defence of Cape Coast Castle in 1791. When he refused... his stipend was stopped. Thus by the linking of missionary with the...colonial powers, the former was left to the caprices and whims of the politician. (Pobee 2006, 127)

This story represents another example of how the Anglican Mission was seriously compromised by the link between the English Church and the state. Quaque continued to serve until his death (1816). However, the scope of the SPG's work was limited by the colonial horizons of its mission. Pobee goes so far as to argue that the SPG's initial presence did not impact much upon the Ghanaian people for it was little more than a 'chaplaincy to the British government officials' (2006, 93). Whether or not this is correct, it is clear that the SPG made no systematic attempt to organise any systematic missionary work until the start of the twentieth century (Groves 1955, 213; Kpobi 2008, 79; Smith 1966, 22-23).

When the Church of England resumed full evangelisation work in Ghana, Nathaniel Temple Hamlyn was appointed to serve as bishop with charge of the Gold Coast (1904-1910). By this time the SPG had come under the influence of the descendants of the Oxford Movement. Although Hamlyn had served with CMS in Nigeria, he pursued High Church traditions. Hamlyn's mission focus was also directed towards the elite. Pobee writes:

Hamlyn was orientated to the elite, i.e the wealthy merchants, higher professionals and civil servants. This elitist orientation fits well with the psyche of High Church tradition. (Pobee 2006, 143)

While Pobee (2006) attributes Hamlyn's orientation toward the elite with his 'High Church' tendencies, these features of the Anglican tradition are not necessarily related. For example in the late nineteenth century Anglo-Catholics like Charles Fuge Lowder (1820-1880) and Alexander Heriot Mackonochie (1825-1887) made an enormous impact upon the lives of the urban working classes of Victorian Britain. ${ }^{22}$ It is far more likely that Hamlyn's selectiveness was due to his important status within a state church at the height of the British Empire.

Hamlyn retired to England after six years on the Gold Coast (1910). He was succeeded by Stephen Mowbray O'Rorke (1913-1924) who introduced a number of Anglo-Catholic practices (Sacramentalism, Sacerdotalism, Vestments etc.). ${ }^{23}$ Early on in his ministry O'Rorke oversaw the establishment of new churches such as the church in Larteh, in the Akwapim mountain range (1913). However, by the time the Anglicans had arrived in this area the Basel Mission had been ministering there for eighty years (Pobee 2006, 150; Smith 1966, 30). ${ }^{24}$ Here it is important to acknowledge that O'Rorke was conscious of the factors which led to the listlessness of the Anglican Mission to Ghana: 
We must be asked, Have our Missionary Methods hitherto sufficiently been well-thought out and carefully planned? Has sufficient respect been given to native ideas, not to say faith and age-long customs? The answer is in the negative... We have gone to work in the past upon the "unsound" foundation that the heathen...make a complete break with his past in every respect. (O’Rorke 1922, 9)

Though it was not until his departure (1924) that a theological college was finally begun, O'Rorke understood that the success of the Anglican Mission depended upon the development of Ghanaian leadership. He himself ordained two Ghanaian priests (1916). Nevertheless, while he was keen to prepare local people for ordination, his invitation to the Benedictine order of Pershore Abbey to set up an institution for training Ghanaian Anglican priests was accepted on the condition that they would be allowed to use Latin for daily prayers and Mass (Pobee 2006, 149-150). Training priests within this environment would hardly provide them with the tools necessary to engage the average Ghanaian. ${ }^{25}$

O'Rorke's work was also hampered by the colonial authorities. A follower of the Prophet Wade Harris (1860-1929), John Swatson, offered the 'fruits of his labour' to the Anglican Church in Ghana. Unfortunately the relationship with Swatson was 'soured' when the district commissioner deemed it 'undesirable' that the bishop give Swatson, a non-European, any influence within the church. This story illustrates how a creative approach to mission, to build the Anglican Church on foundations laid by an indigenous pioneer of the Gospel, were stunted by the interference of the colonial government (Pobee 2006, 155-156).

When John Aglionby (1924-1951) became Bishop of Accra (1924) there were only three African clergy. Like O'Rorke he also recognised that this was a hindrance to mission:

Beyond all things, West Africa needs leaders of its own race in every department of life, but above all men of spiritual power. (O’Connor 2000, 414)

Aglionby was true to his word for a permanent site was soon set up for St Augustine's Theological College in Kumasi (1928). ${ }^{26}$ The number of native clergy increased tenfold during Aglionby's episcopate (numbering 32 in 1949). Even though these statistics are impressive, the Presbyterian Church had been training ministers for over a century (since 1848) by this point in time (Pobee 2006, 156-159; Smith 1966, 54). Whilst it is clear that Aglionby presided over a growing church, Pobee considers that at times the clerical and sacramental emphasis held back the mission. He writes:

A church that is Anglo Catholic is necessarily sacerdotal, so that the various sacraments can be administered by the clergy. But a mission at its beginnings can never have enough clergy to go round the needs of ministration of sacraments. (Pobee 2006, 160)

Thus Pobee considers that this sacramental emphasis, coupled with Aglionby's clerical approach to church leadership, did not always lend itself to the needs of the Ghanaian context (Pobee 2006, 171). 
Bishop John Charles Sydney Daly (1951-1955) presided over a very different situation to his predecessor. In contrast to Aglionby, who was appointed when Britain's colonial power was still strong, Daly served when the Gold Coast was in the midst of considerable political agitation; during the twilight of the empire. $\mathrm{He}$ was thus very sensitive to the potential problems that an English colonial church might have in a nationalistic age. In response to this Daly ensured that the name of the Diocese, the 'English Church Mission' was changed to the Anglican Church. While this was a positive if not essential move for ensuring the church's survival, post-independence (1957), it did not go far enough (Pobee 2006, 170-171). Pobee writes:

It is my conviction and proposal that the very name "Anglican" which means "English" needs to be revisited and changed. It is odd for a bona fide African to carry the description "Anglican" (English). Such a situation reveals something of an English captivity of the Anglican Church in Ghana [own emphasis]. (Pobee 2006, 395)

While Daly felt that a change of name would assist the church to become truly Ghanaian it is incredible that a Ghanaian church should be called English. ${ }^{27}$ Pobee's (2006) contention that an Anglicised name is also symptomatic of a deeper problem within the church is indicated by the fact that the SPG's Mission to Ghana has been very slow to translate its liturgies and rich hymnody into the vernacular. ${ }^{28}$ The question is, why were the SPG not committed to the translation of central aspects of the Anglican tradition into Ghanaian languages? One possible reason for this is the deprecation of Scripture found in some Tractarian writers.

In a sermon, given on behalf of the SPG (1839), Pusey (1859) openly criticised the model of evangelisation which involved the circulation of the Bible in the vernacular:

It were indeed almost incredible to us, (but that we live in times when people are daily and systematically acting upon the supposition,) that any could have maintained, that the mere circulation of the printed Bible would convert the heathen...The desultory way in which Missionaries are sent out, not responsible, or, in the best cases, scarcely responsible, to Bishops, under no control except of such as have no right to any control over them, departs as widely from the Apostolic and Scriptural plan of converting the heathen, as that of circulating the Scriptures only; and is likely in the end to produce mischievous effects. (Pusey 1859, 42)

Here Pusey (1859) lambasts the practice of circulating Bibles by missionaries because of his firmly rooted belief that Scripture alone cannot teach doctrine but requires instruction to expound its true meaning. ${ }^{29}$ Whether or not this is the case, it remains clear that the lethargic efforts of the SPG to translate the Scriptures and other aspects of the Anglican tradition into the vernacular are commensurate with this AngloCatholic underestimation of the value of Scripture for converting unbelievers. This point is also highlighted by the contrasting way in which the Ghanaian Presbyterians, 
firmly rooted in the Reformed tradition, were reading the Scriptures in their own language by the mid-nineteenth century.

The Basel Mission instructed all its recruits to 'become acclimatised' and 'master the local language at all costs' (Smith 1966, 28-29). As early as 1844 the first Twi ${ }^{30}$ hymn was sung, the first sermon was preached in Twi (without an interpreter), and the first Twi school begun. ${ }^{31}$ Soon after this the Scriptures were translated into Twi:

Johannes Gottlieb Christaller, was commissioned...to devote himself solely to the Twi language, the most widely-spoken in the Gold Coast...Six years after his arrival in Akropong, in 1859, Christaller was able to publish the four Gospels and the Acts...Three years later he brought his translation of the entire Bible in manuscript to Europe, an outstanding piece of work which showed him to be a linguist of the first rank. (Smith 1966, 54-55) ) $^{32}$

All of this illustrates the stark difference between the approach taken by the Basel Mission Committee - which insisted that people hear the Gospel in their own tongue - and the Anglican Mission. The model of evangelisation adopted by the Presbyterians, which gave value to the Ghanaian language, is vindicated by its considerable accomplishments in effectively communicating the Gospel.

The importance that Anglo-Catholics give to the role of the episcopate is demonstrated by Daly's successor, Bishop Reginald Roseveare (1956-1967). Roseveare was from the High Church tradition, a monastic from the Society of the Sacred Mission (Kelham, Nottinghamshire). It is unfortunate that this instilled him with an authoritarian conception of episcopacy that revealed itself in his tendency to confuse obedience to the church with obedience to himself. One example of this is that when those training for the priesthood refused to join his monastic order, he equated this with a refusal to obey not only the bishop's wish but 'the voice of God echoed in the Bishop's voice' (Pobee 2006, 180-181). This conception of episcopacy resembles that which is found in Newman's correspondence (quoted in Tracey 1984) with the Bishop of Oxford, Richard Bagot (1782-1854; Bishop 1829-1845) after Bagot had expressed some concerns about some of his Tracts for the times:

My dear Lord...It has ever been my wish to approve my words and acts to your Lordship's judgment...I have ever considered that...the formal expression of your feelings in any matter ought to be my rule. As to the Tracts...I felt it impossible to entertain the idea of allowing them to continue [and] I shall feel a more lively pleasure in knowing that I am submitting myself to your Lordship's expressed judgment, in a matter of this kind, than I could have even in the widest circulation of the [Tracts] in question. (Tracey 1984, 129-130)

This extract indicates the profound respect that Newman had for his bishop. So much so that should his bishop request it, he would immediately stop writing Tracts. ${ }^{33}$ Roseveare's conception of episcopacy clearly resonates with this view. It is regrettable that this dictatorial approach undermined his ministry in Ghana. ${ }^{34}$

In summary, it seems that although the SPG made an important contribution to the spread of Christianity in Ghana its ministry has been weighed down by its 
connection with the occupying colonial power. This has served to shackle the church to Anglo-Saxon culture and has impeded the assimilation of its traditions into the Ghanaian context. Moreover, the underestimation of the Scriptures, veneration of the episcopate, clericalism, the use of Latin in the celebration of the sacraments and other Anglo-Catholic tendencies, appear to have hampered the mission's success. All of these factors, when combined, have contributed to the general failure of this church to translate its traditions into the vernacular. The real question is, which aspects of the Anglican heritage need to be jettisoned, and which aspects need to be maintained if this church is to become fully Ghanaian?

\section{Realising Afro-Catholicism}

\section{De-Anglicising Ghanaian Anglicanism}

Having examined some of Anglicanism's characteristics, and how these may have impacted upon its mission to Ghana, a number of issues come to the fore. It is quite possible that an Anglicised label of identification has been a barrier to the assimilation of this Christian tradition within the Ghanaian context. Though Ghanaian Anglicanism has no formal connection with either the English or Ghanaian state, Pobee (2006) suggests that this church's colonial heritage has endowed it with an establishment mentality. He considers Anglicanism to be 'notoriously middle class in ethos' (Pobee 2006, 4). He writes:

[While] efforts are made to inculturate the essence of Anglicanism...In Ghana there has been some addiction to the English model and clergy have tended to be clones of the middle class gentleman of the English context and their impact is somehow dulled. (Pobee 2006, 223)

If Pobee is correct, it would appear that the inculturation of Anglicanism in Ghana may have been impaired by a hereditary elitism inherent within the English class system and alien to the Gospel of Jesus Christ.

Having argued that this Episcopal Ghanaian Church should discard a number of Anglo-Saxon impediments, the question must be asked: Should this Ghanaian church assimilate the Catholic emphasis bequeathed to it by the SPG or should it abandon this Catholic emphasis altogether? It is impossible for an Englishman, an outsider to Ghanaian culture, to provide any meaningful answer to this question. ${ }^{35}$ Nevertheless, whatever direction is taken, it remains clear that the Anglo-Catholic tradition could be enriched by a number of aspects from Ghanaian culture, for example the Akan concept of Okra, the priesthood, and the Ashanti stool.

\section{Okra: A sacramental principle?}

The Ghanaian concept of man is both physical and spiritual. For example, the Akan believe that each person is inhabited by Okra: a spiritual principle. This 
means that a greater power is at work in human affairs. Events that appear ordinary have transcendental origins and implications (Opoku 1978, 94-95). According to Okoledah:

Precisely because of these close connections between and intermingling of material and immaterial elements in man, and the situating of the origin, context and purpose of human life in a spiritual framework, there is scarcely any dichotomy between the corporeal and the incorporeal, or the spiritual and the bodily in reference to man. (Okoledah 2005, 12)

Here Okoledah (2005) points out that the Akan believe human existence to be saturated with the supernatural. This understanding dovetails with the sacramental understanding of reality found in the writings of High Anglican churchmen.

An important contribution made by the Oxford Movement, to which the AngloCatholic tradition (and indeed the SPG) owes a considerable debt, is its sacramental view of Christianity (Crockett 1989, 215). This view is typified by Newman (2008) who believed that God's grace is mediated by physical realities. He writes:

The Sacramental system; that is, the doctrine that material phenomena are both the types and the instruments of real things unseen, - a doctrine, which embraces in its fullness, not only what Anglicans, as well as Catholics, believe about Sacraments properly so called. (Newman 2008, 148)

Hence, Newman (2008) considered that the physical world was governed by a sacramental law; that the visible world is but an outward manifestation of spiritual principles. When viewed from this perspective baptism and Holy Communion are believed to be attended by Divine Grace. ${ }^{36}$ Hence it seems that parallels exist between the sacramental principle common to Anglo-Catholic writers and the Akan belief that the supernatural pervades all aspects of human existence.

\section{Akan concepts of priesthood}

In addition to the above it appears that the concept of priesthood in Akan (Akomfo) may also dovetail with Anglo-Catholic thought:

Akomfo function as intermediaries between their communities and the deities into whose service they have been called. In a typical priestly capacity, they present the community's needs to the deities, and interpret the latter's wishes to the community. Their close contact with the spirit world places them in an extraordinary position, their very persons being regarded as sacred. (Ekem 2008, 53)

Therefore, as priests in the Anglo-Catholic tradition are considered to be direct descendants of the priesthood of Christ, so the Akan concept of priesthood views itself as a living institution continuous with its past. Furthermore, as Anglo-Catholic priests are understood to be the legitimate mediators between God and the people because their authority to perform sacerdotal functions comes from their unbroken 
connection to the Apostles - so Akan priests are the custodians of Akan traditional spirituality and function as sacral mediators (Ekem 2008, 53,56,118). This indicates that if the Anglican missionaries had taken more time to explore the customs and culture of the Akan, it is likely that their mission would have been more successful and that the Anglo-Catholic sacramental tradition would have been enriched. ${ }^{37}$

\section{An Apostolic stool?}

Another potential way in which the SPG might have been enriched is by exploring parallels between the Akan stools and the notion of 'Apostolic succession'. In the Akan culture, stools carved out of a single piece of wood, act as symbols of authority. In fact they are an indispensible condition of Ashanti leadership:

The stools of a chief are identified not only with the man but with his office as well. Stools of political leaders therefore symbolize the unity of the state and the authority of the ruler. Stools are in fact the Sine qua non of Ashanti leadership. (Fraser and Cole 2004, 142)

Hence chiefs consider stools as their supreme emblem. Furthermore, stools are the first gift from a father to a son and even the personal stool of a king who is deposed may be retained for use as a ceremonial stool by succeeding rulers (Fraser and Cole 2004, 142).

As was discussed earlier, 'Apostolic succession' is the idea that the bishops have an unbroken chain of authority going right back to the Apostle Peter. Thus, when one bishop consecrates another, this symbolises the passage of Christ's authority going down through the ages. It is possible that this might in some way be commensurate with the concept of the stool in Akan culture. Thus, as one bishop succeeds another, an 'Apostolic stool succession' could occur in which a royal stool could be given to symbolise the conferring of apostolic authority from one bishop to another. This parallel suggests that the SPG could have contextualised the notion of 'Apostolic succession' within the Akan culture by using a native symbol of authority, such as the stool.

In summary it seems that the potential for exploring further parallels between Akan culture and the High Church tradition would be mutually enriching to both British Anglo-Catholics and Ghanaian Christianity. Had the SPG fostered a different attitude towards Ghanaian culture then a genuine Afro-Catholicism may have been developed.

\section{Conclusion}

In conclusion it seems that while the Anglo-Catholic Mission to Ghana was impeded by colonialism, clericalism and dictatorial models of leadership, it also had great potential. Had the SPG sought to identify its High Church traditions more closely with the local Ghanaian culture, then it appears that a genuine inculturation 
could have taken place. However, if this Afro-Catholic vision is to be realised it will be necessary for this Episcopal Church to be de-Anglicised. Thankfully it is for Ghanaians to determine the theological course taken by this church. ${ }^{38}$

\section{ENDNOTES}

1. Although the term 'Anglo-Catholic' was not widespread until the nineteenth century, throughout its history groups within the Church of England have insisted upon affirming its Catholic heritage

2. This was a separation from both his wife, Catherine of Aragon (1533) and the Pope (1532) Clement VII (1478-1534).

3. It is important to emphasise that Henry never formally rejected Catholic doctrine. He died a Catholic. His issue was not with the Catholic faith but the intrusion of papal power into his domestic affairs.

4. Erastianism, named after the Swiss theologian Thomas Erastus (1524-1583), is the belief that the state has the right to intrude upon the affairs of the church.

5. While Elizabeth changed this title to 'Supreme Governor' the close connection between this church and the English state is evidenced by the fact that the Archbishop of Canterbury is chosen by the British Prime Minister.

6. This is not to suggest that the Reformed credentials of the Church of England are questionable but that its strong sense of Catholicity is due to its distinctive origins. Pobee rightly points out that the 'winds' of reform were blowing all over Europe at this time (2006, 15-17).

7. This is often referred to as the Via Media of the Anglican Church.

8. Here Antiquity refers to the tradition of the early church.

9. Here it is important to acknowledge that Newman, while leading the revival of AngloCatholicism in the early nineteenth century (1833-1841) later joined the Roman Catholic Church (1845).

10. Article VI.

11. Waterland (1856) writes: 'That the Church of England has a very particular regard to Antiquity, may sufficiently appear from a Canon set forth in the same year when our Articles were first perfected and authorised by act of parliament, namely, in the year 1571. By that Canon it is provided, "that preachers shall not presume to deliver anything from the pulpit, as of moment, to be religiously observed" and believed by the people, but that which is agreeable to the "doctrine of the Old or New Testament, and collected out of the same doctrine by the Catholic Fathers and the Bishops of the ancient church" ' (Waterland 1856, 653-654). For further examples see Bramhall (1845, 53); Bull (1844, 234); Hawkins (1818); Newman, (1836, 379).

12. Wood, Newman's student and friend, writes: 'Newman holds that from the time the Church ceased to be one, the right of any part of it to propound articles of faith, as such, is suspended; all that remains to them is to impose terms of communion, articles of 
peace, etc. Further, he says that before the Reformation the Church never deduced any doctrine from Scripture and by inference blames our reformers for doing so, moreover he objects to their doctrine in itself as to justification by faith, and complains of their attempt to prove it from the Fathers, as a perversion of their meaning. Generally, his result is, not merely to refer us to Antiquity but to shut us up in it, and to deprive, not only individuals but the church of all those doctrines of Scripture not fully commented on by the Fathers; and he seems to consider that our Reformed Church has erred' (Purcell, 1895, 221-2). For Rose's reflections upon this see Burgon (1888, 210,219).

13. This is evidenced by the Nonjurers and the Tractarians who both used tradition in order to legitimate Anglican identity in separation from the English state. For further discussion see Gascoigne (1997, 60-79).

14. The Corporation Act (1661) prevented non-Anglicans standing for public office.

15. According to Faught: 'Essentially this move carried with it the complete destruction of the Anglican confessional state, the religio-political compact that ensured the privileged position of the Church of England during the whole of the eighteenth century' (Faught 2003, 3ff).

16. Even in 1928 a new Prayer Book was cancelled because parliament voted against it. Bishop Hensley Henson wrote: 'The rejection of the Prayer Book implies that to acquiesce in such subordination of the church to the state is to allow the claim of Caesar to override the claim of God. Whatever fortunes be reserved for the Church of England, may God, in his mercy, preserve it from the ignominious security of a tame church in a secularised state' (Kent 1992, 174ff).

17. In time, this craving led some to join the Roman Catholic Church. For further discussion see Newman (1845).

18. Tractarian is the nickname for members of the Oxford Movement - Anglican clergymen who composed Tracts (pamphlets) which beseeched the Church of England to return to the doctrines and practices of the undivided Church of Antiquity.

19. As Gascoigne explains: ' ...if the bishops provided leadership and institutional continuity it was possible for the church to exist independently from the state' (Gascoigne 1997, $62)$.

20. 'Apostolic succession': The notion that the bishops of the Anglican Church have an unbroken connection with the Apostles.

21. This calls into question Avis' contention that, despite its Erastian features, Anglicanism has retained its own inner integrity. This does not appear to be the case within the colonial framework operative within the Gold Coast. For further discussion see Avis (2002, xiv).

22. According to Parsons (1988) figures like these 'demonstrated publicly and dramatically the self-conscious commitment of Anglo-Catholics and Ritualists to the mission to convert the urban poor...They were themselves a symbol of the determination of second generation Anglo-Catholics to take the sacramentalism of the Oxford Movement - its emphasis on eucharistic presence and sacramental priesthood into the urban, workingclass environment. Colour, ritual, music, processions, eucharistic worship, the renewal of baptismal vows and the confessional were attempts to embody Tractarian ideas 
in forms and actions which were accessible to poor, uneducated and theologically unsophisticated people. Indeed, some Anglo-Catholics were quite explicit in arguing that whereas evangelical Protestantism offered the poor only subjective experience and sermons...Anglo-Catholicism offered sacraments and symbols which provided an objective presence capable of being grasped by the poorest and least educated' (Parsons 1988, 239).

23. An indication of the level of Mowbray's interest in the High Church tradition of Anglicanism is his retirement to Walsingham when he left Ghana.

24. The Basel Mission arrived on the Gold Coast in c. 1835.

25. Here Pobee is right to point out that 'Anglican missions will come to nothing unless they are cultured in the Ghanaian reality, engaging the heart, soul and body of the Ghanaian' (Pobee 2006, 160).

26. He also invited the Order of the Holy Paraclete (OHP) of Whitby England to set up a mission to women in Ghana. St Monica's convent was established (1926). However, until the late twentieth century there was only one Ghanaian member of the order (Pobee, 2006, 162-3)

27. Despite these criticisms it is important to acknowledge that it was Daly who appointed the first Ghanaian bishop, Ezra Douglas Martinson (1951-1968) (Pobee 2006, 174-176).

28. Pobee writes: 'Today in Ghana we are aware that we need to use the vernacular. But all too often it is limited to translating texts crafted in English with English mentality. For language is not only words to be translated; it is more importantly, the idiom and worldview of a people and their way of doing things' (Pobee 2006, 123-124).

29. The same view is found in Newman's writings. For further discussion see Newman (1901, 9-16); Ker and Gornall $(1979,97)$.

30. Twi is the principle native language of Ghana.

31. It is telling that their attempts to learn the Twi language were 'mocked' by other resident Europeans (Smith 1966, 39).

32. The Akrofi-Christaller Institute of Theology Mission and Culture, founded by Kwame Bediako (1945-2008), was named after this great scholar of the Twi language, Johannes Gottlieb Christaller (1827-1895); and another pioneer figure in the cultural witness of the Church in Ghana, Clement Anderson Akrofi (1901-1967).

33. Newman considered that a 'Bishop's lightest word ex Cathedra is heavy'. When he became a Roman Catholic he said that he had always obeyed his own bishop (Bagot) as though he was the pope (Newman 2008, 196, 283).

34. Pobee $(2006,180 \mathrm{ff})$ considers that this style of leadership hampered the progress of the ecumenical movement in Ghana considerably.

35. When studying a culture or a religion there is always an 'insider/outsider' problem. The issue is, how can someone who is an outsider study the beliefs, words, or actions of someone who is native to that culture. For further discussion see McCutcheon (1999, 1-11).

36. Thus Newman believed that earthly things, like bread and wine, are attended by Divine Grace in the sacrament of Holy Communion: 'We call His presence in this Holy 
Sacrament a spiritual presence, not as if "spiritual" were but a name or mode of speech, and He were really absent, but by way of expressing that He who is present there can neither be seen nor heard; that He cannot be approached or ascertained by any of the senses; that $\mathrm{He}$ is not present in place, that $\mathrm{He}$ is not present carnally, though $\mathrm{He}$ is really present. And how this is, of course is a mystery. All that we know or need know is that He is given to us, and that in the Sacrament of Holy Communion' (Newman 1906, 136137).

37. Ekem considers that the Western missions to Ghana could have developed their notions of the priesthood if they had taken more serious note of important values within the Akan traditional priesthood. One example given is the role played by women (Ekem 2008, 57 , 119)

38. I would like to thank J.S. Pobee and my father-in-law T.K.A. Pratt for their encouraging and incisive comments..

\section{LIST OF REFERENCES}

Avis, P. 2002. Anglicanism and the Christian church. London: T \& T Clark.

Beveridge, W. 1837. Sermons on the ministry and ordinances of the Church of England. Oxford: John Henry Parker.

Bowles, W. 1831. The life of Thomas Ken, Vol. I. London: John Murray.

Bramhall, J. 1845. The works of the most Reverend John Bramhall, Vol. V. Oxford: John Henry Parker.

Bull, G. 1844. Examen Censurae: Or, an answer to certain strictures on a book entitled Harmonia Apostolica. Oxford: John Henry Parker.

Burgon, J.W. 1888. Lives of twelve good men, Vol. I. London: John Murray.

Crockett, W.R. 1989. Eucharist: Symbol of transformation. Collegeville MN: Pueblo.

Ekem, J.D.K. 2008. Priesthood in context: A study of priesthood in some Christian and primal communities of Ghana. Accra: Sonlife.

Faught, C.B. 2003. The Oxford Movement: A thematic history of the Tractarians. Pennsylvania State University Press.

Fraser, D. and Cole, H. eds. 2004. African art and leadership. Milwaukee, WN: University of Wisconsin Press.

Gaines, K.K. 2006. American Africans in Ghana. Chapel Hill, NC: University of North Carolina Press.

Gascoigne, J. 1997. 'The unity of church and state challenged: Responses to Hooker from the Restoration to the nineteenth century Age of Reform,' Journal of Religious History 21: 6079.

Gilley, S. and Stanley, B. eds. 2006. The Cambridge history of Christianity. Cambridge University Press.

Groves, C.P. 1955. The planting of Christianity in Africa, Vol. III. London: Lutterworth Press.

Hawkins, E. 1818. A dissertation upon the use and importance of unauthoritative tradition as an introduction to the Christian doctrines. Oxford: Rivington. 
Hooker, R. 1821. The works of Mr Richard Hooker in eight books of the laws of ecclesiastical polity, Vol. I. ed. I. Walton, W. Clarke. London.

Jebb, J. 1839. A Tract for all times: Peculiar character of the Church of England: As distinguished both from other branches of the Reformation and from the Modern Church of Rome, ed. F. Huyse. London: Rivingtons.

Jewel, J. 1839. An apology of the Church of England, trans. W. Withers Ewbank, R.B. Seeley and W. Burnside. London.

Keble, J. 1848. Sermons, academical and occasional. Oxford: John Henry Parker.

Kent, J. 1992. William Temple: Church state and society in Britain, 1880-1950. Cambridge University Press.

Ker, I. and S.J. Gornall eds. 1979. Letters and diaries of John Henry Newman, Vol. II. Oxford University Press.

Kpobi, D.N.A. 2008. Mission in Ghana: The ecumenical heritage. Accra: Asempa.

Losch, R. 2002. The many faces of faith: A guide to world religions and Christian traditions. Grand Rapids, MI: Eerdmans.

McCutcheon, R.T. 1999. 'General introduction.' In The insider/outsider problem in the study of religion, R.T. McCutcheon ed. London: Cassell.

Newman, J.H. 1833. Thoughts on the Ministerial Commission: Respectfully addressed to members of the clergy, http://www.newmanreader.org/works/times/tract1.html (accessed 8 October 2014).

Newman, J.H. 1834. The Catholic Church, http://www.newmanreader.org/works/times/tract2. html (accessed 8 October 2014).

Newman, J.H. 1836. 'Lectures on the principal doctrines and practices of the Catholic Church by Nicholas Wiseman, D.D. London: Booker. 1836,' The British Critic 19: 373-403.

Newman, J.H. 1837. Lectures on the prophetical office of the church. London: Rivington.

Newman, J.H. 1845. An essay on the development of Christian doctrine. London: J Toovey.

Newman, J.H. 1901. The via media of the Anglican Church, Vol. II. London: Longmans Green.

Newman, J.H. 1906. Parochial and plain sermons, Vol. VI. London: Longmans Green.

Newman, J.H. 2008. Apologia Pro Vita Sua and Six Sermons, ed. F. Turner. New Haven, CT: Yale University Press.

O'Connor, D. ed. 2000. Three centuries of mission: The United Society for the Propagation of the Gospel 1701-2000. London: Continuum.

O'Rorke, M.S. 1922. Life and work in the Diocese of Accra during 1922. Report to SPG. Unknown Publisher.

Okoledah N.D.K. 2005. Problems and prospects of the search for a Catholic spiritual tradition in the Ghanaian Catholic Pastoral Ministry. Munster: Lit Verlag.

Opoku, K.A. 1978. West African traditional religion. Accra: FEP International.

Parsons, G. 1988. 'Emotion and piety.' In Religion in Victorian Britain, G. Parsons ed. Manchester University Press, pp. 213-234.

Pobee, J. 2006. The Anglican story in Ghana. Accra: Amanza.

Purcell, E.S. 1895. Life of Cardinal Manning, Archbishop of Westminster, Vol. I. London: Macmillan. 
Pusey, E.B. 1859. The church, the converter of the heathen: Two sermons preached on behalf of the society for the propagation of the Gospel. Oxford: Henry and Parker.

Smith, N. 1966. The Presbyterian Church in Ghana 1835-1960: A younger church in a changing society. Ghana Universities Press. Accra: Legon.

Tracey, G. ed. 1984. Letters and diaries of John Henry Newman, Vol. VI. Oxford University Press.

Waterland, D. 1856. The works of the Rev. Daniel Waterland, Vol. III, ed. W. van Mildert. Oxford University Press. 